Egyptian Veterinary Medical Society

of Parasitology Journal

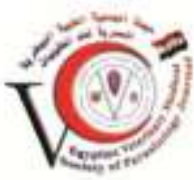

Original Article

\title{
Comparative study for diagnosis of babesiosis and theileriosis in different age groups of cattle in some localities in Egypt with treatment trials
}

\begin{tabular}{|c|c|}
\hline $\begin{array}{l}\text { Mona Mohammed I. } \\
\text { Abdel Rahman }^{1} \text { and } \\
\text { Wafaa Mohamed } \\
\text { Ismaiel }^{2} \\
{ }^{1} \text { Parasitology and } \\
{ }^{2} \text { Animal medicine } \\
\text { Dept., Faculty of Vet. } \\
\text { Med., Zagazig } \\
\text { University. } \\
\text { Zagazig,Egypt }\end{array}$ & $\begin{array}{l}\text { Babesia bovis, Babesia bigemina, Theileria annulata are the most } \\
\text { important endemic blood parasites in Ismailia and Sharkia Provinces, } \\
\text { Egypt, which transmitted by ticks causing babesiosis and theileriosis } \\
\text { which characterized by fever, enlarged lymph nodes, pale mucous } \\
\text { membranes and may lead to death. Therefore, the aim of our study is to } \\
\text { determine the infection rates of B. bovis, B. bigemina and T. annulata in } \\
\text { relation to age. We found that the rates by staining method were as the } \\
\text { following: } 12.90 \%, 6.45 \%, 38.71 \% \text { and } 4.84 \% \text { for B. bovis, B. bigemina, } \\
T \text {. annulata and mixed infection, respectively, while by polymerase chain } \\
\text { reaction (PCR) the rates were } 35 \%, 20 \%, 60 \% \text { for B. bovis, B. bigemina } \\
\text { and T. annulata, respectively. This study confirmed the incidence of } \\
\text { infection with Babesia and Theileria species in relation to age group of } \\
\text { animals was } 77.78 \% \text { in adult age group, } 66.67 \% \text { in less than } 3 \text { months age } \\
\text { group and } 53.19 \% \text { in } 3-6 \text { months age group. Also, our study proved that } \\
\text { the use of imidocarb and buparvoqune beside acaricides considered a good } \\
\text { choice for treatment. Although our results proved that using of specific } \\
\text { primers in PCR was a rapid and an accurate method for differential } \\
\text { diagnosis between Babesia and Theileria species in cattle, we found that } \\
\text { the use of staining method was more helpful especially in mixed infection } \\
\text { cases. In the end, we recommend using both methods together to get better } \\
\text { results. }\end{array}$ \\
\hline & Keywords: Age, Babesia, Egypt, Giemsa, Polymerase Chain Reaction, \\
\hline
\end{tabular}

\section{INTRODUCTION}

Babesiosis and theileriosis are the most important haemoparasitic diseases in veterinary medicine. The incidences of these diseases constitute a significant economic loss as they cause a marked decline in the rate of meat, milk production and sometimes death in cattle. In addition, the infected cattle suffered from fever, anemia, haemoglobinurea, jaundice, lethargy and enlarged lymph nodes, especially in the acute stage of infection Inci et al. (2007). On the contrary, the infected cattle become asymptomatic in the chronic stages. 
When hard ticks attacked cattle to take blood meal, Babesia species sporozoites released and transformed into trophozoites inside the red cells. While, Theileria sporozoites invaded lymphocytes and then schizogony and merogony were performed Zintl et al. (2003).

In Egypt, Babesia bigemina and Babesia bovis were the most common causes of bovine babesiosis Nagati (1947). While, theileriosis was mainly caused by Theileria annulata El-Ashker et al. (2015). The recovered animals from acute infection might remained as carriers for the infection Brown (1990).

The blood staining method might be insufficient in the detection of infection in carriers, so we found an essential need to diagnose them by using conventional PCR method. The diagnosis of blood parasites by microscopical examination of Giemsa stained blood smears required a lot of effort, especially in the herds of large animals, in addition to the lack of accurate results in the case of light and chronic infection Calder et al. (1996) and Mosqueda et al. (2012), so it was necessary to use PCR and compare the obtained results with those obtained by microscopical examination of the stained blood smears. So, our study aimed to evaluate the efficiency of Giemsa staining and conventional PCR methods as a rapid and accurate diagnostic tool for detection of Babesia bovis,
Babesia bigemina and Theileria annulata infection in cattle in Egypt. As well as, our study determined the best method for treatment of the infected cattle.

\section{MATERIAL AND METHODS}

\section{Collection of animals:}

Total number of cattle examined was 124 (104 from Wadi Almullak farm at Ismailia province and 20 cattle from different localities admitted to the Veterinary Clinic, Faculty of Veterinary Medicine; Zagazig University, Sharkia Province, Egypt. Examined animals were classified according to the age into three groups:

a) Adult group $\geq$ three years.

b) Young group less than three months.

c) Young group three-six months (Table 1).

Cattle were clinically examined according to Rosenberger et al. (1979).

This study was ethically approved by ZU-IACUC Committee, Zagazig University, Egypt

(ZUIACUC/2/F/5/2018).

\subsection{Animal management:}

The examined cattle at Wadi Almullak were suffering from low hygienic condition and overcrowding. The animals were collected from different markets beside some imported cases and there was a continuous entry of new cattle to the farm.

\section{Collection of the blood samples:}

We collected the blood samples in tubes containing EDTA from the tail vein of cattle infested with hard 
tick and suffered from increasing in their body temperature. Some animals showed enlargement in prescapular and prefemoral lymph nodes, lacrimation with pale conjunctival mucous membrane, loss of appetite and decrease in their body weights. The collected blood samples kept at $-20^{\circ} \mathrm{C}$ until DNA extraction.

\subsection{Blood film preparation}

We immediately spread thin blood film, then fixed with methanol for 20 minutes and stained with freshly prepared Giemsa stain 25\% for one hour. The stained films examined under oil immersion lens to identify and differentiate trophozoites of Babesia bovis, Babesia bigemina and Theileria annulata according to the characters described by Soulsby (1982).

\section{Molecular characterization} (PCR assay)

DNA extraction from blood samples was performed using the QIAamp DNA Mini kit (Qiagen, Germany, GmbH) with modifications from the manufacturer's recommendations. Briefly, $200 \mu \mathrm{l}$ of the blood sample was incubated with $10 \mu \mathrm{l}$ of proteinase $K$ and $200 \mu$ of lysis buffer at $56^{\circ} \mathrm{C}$ for $10 \mathrm{~min}$. After incubation, $200 \mu \mathrm{l}$ of $100 \%$ ethanol was added to the lysate. The sample was then washed and centrifuged following the manufacturer's recommendations. Nucleic acid was eluted with $100 \mu \mathrm{l}$ of elution buffer provided in the kit. The used primers were supplied from Metabion (Germany). They were listed in (Table 2).
Primers were utilized in a $25-\mu l$ reaction containing $12.5 \mu \mathrm{l}$ of Emerald Amp Max PCR Master Mix (Takara, Japan), $1 \mu \mathrm{l}$ of each primer of 20 pmol concentration, $4.5 \mu \mathrm{l}$ of water, and $6 \mu \mathrm{l}$ of DNA template. The reaction was performed in an applied biosystem 2720 thermal cycler. The products of PCR were separated by electrophoresis on $1.5 \%$ agarose gel (Applichem, Germany, GmbH) in $1 \mathrm{x}$ TBE buffer at room temperature. The gel was photographed by a gel documentation system (Alpha Innotech, Biometra) and the data was analyzed through computer software. PCR was performed in Animal Health Research Institute, Dokki, Egypt.

\section{Treatment trials for babesiosis and theileriosis}

Individual cases of cattle suffered from theileriosis were treated with buparvoquone (Avico Company, Jordan) at dose of 2.5 $\mathrm{mg} / \mathrm{kg}$ intramuscular for two times with 72 hours interval. While, cases suffered from babesiosis were treated with imidocarb dipropionate (Adwia Company, Egypt, 1.2 $\mathrm{mg} / \mathrm{kg}, \mathrm{s} / \mathrm{c}$ ) plus application of acaricides on cattle skin and surrounding environment. While, in a Wadi Almullak farm; dipping path was absent and the acaricides were randomly sprayed on the skin of infested cattle only and did not apply to the surrounding environment. 


\section{RESULTS}

\section{Clinical findings}

The clinical examination of cattle revealed fever $\left(39-41^{\circ} \mathrm{C}\right)$, anorexia, pale, icteric and congested mucus membrane (Figure 1a, 1b, 1c and 1d) and nervous signs, those lead to suspect that the infection caused by Babesia species. Also, we found enlargement in the superficial lymph node (Fig. 1e), corneal opacity, respiratory manifestation (cough, dyspenea and stretched neck with nasal discharge) and dark red feces, those lead to suspect that the infection was with Theileria annulata. In addition, we observed heavy tick infestation in the skin of cattle (Fig. 1f).

2. Infection rate of Babesia bovis, Babesia bigemina and Theileria annulata in cattle

Microscopical examination of Giemsa stained thin blood smears from 124 cattle revealed that the infection rate was $58.06 \%$. The infection rates were $12.90 \%$, $6.45 \%, 38.71 \%$ and $4.84 \%$ for $B$. bovis, $B$. bigemina, T. annulata and mixed infection (both of $B$. bovis and $B$. bigemina, and $T$. annulata, Fig. 2j), respectively (Table 3). Regarding the occurrence of Babesia species and Theileria species in the examined animals, it was $77.78 \%, 66.67 \%$ and $53.19 \%$ in adult group, less than 3 months group and 3-6 months group, respectively (Table 4).

\section{Morphological identification}

During microscopical examination of stained blood films, we recorded three types of blood parasite trophozoites included Babesia bovis, Babesia bigemina and Theileria annulata. B. bigemina trophozoites were large form measuring 4-5.3 $\mu \mathrm{m} \times 2.0 \mu \mathrm{m}$ and appeared pear shaped. Each trophozoite had one dark stained spot (nucleus) as shown in (Fig. 2a and $2 b$ ). While, $B$. bovis trophozoites were smaller forms measuring $3.0 \mu \mathrm{m} \times 1.5 \mu \mathrm{m}$ and centrally located inside the red cells as shown in (Fig. 2c, 2d and 2e). The two trophozoites made an acute and obtuse angle with each other in B. bigemina and B. bovis, respectively. In addition the red cells infected with Theileria annulata showed varied trophozoite forms (comma shaped, ring form or rod shaped) and measuring 0.5 $1.5 \mu \mathrm{m}$ as shown in (Fig. 2f, $2 \mathrm{~g}, 2 \mathrm{~h}$ and 2i).

\section{Molecular characterization (PCR assay)}

For PCR, the target sequence chosen for amplification was part of the mitochondrial 18s rRNA gene. Those variable regions had shown to be suitable genetic markers for distinguishing Babesia bovis and Babesia bigemina. The length of their PCR products was $356 \mathrm{bp}$ and 278 bp, respectively (Fig. 3a\&3b). While, $T$. annulata amplified segment was 785 bp for Tams1 gene (Fig. 3c). We recorded the infection rates by using PCR and they were $35 \%, 20 \%$ and $60 \%$ for $B$. bovis, $B$. bigemina and $T$. annulata, respectively. 
5. Treatment trials for babesiosis and theileriosis

After treatment with buparvoquone for theileriosis and imidocarb for babesiosis, the individual cases showed rapid response after treatment, while cattle treated at a Wadi Almullak farm did not show clear improvement at the status and new cases of blood parasite infections were recorded.

Table 1. Different cattle age groups examined at Ismailia and Sharkia provinces

\begin{tabular}{|c|c|c|c|c|}
\hline \multirow[t]{2}{*}{ Location } & \multirow{2}{*}{$\begin{array}{l}\text { Number of } \\
\text { cattle } \\
\text { examined }\end{array}$} & \multicolumn{3}{|l|}{ Age group } \\
\hline & & 1-3 month & 3-6 month & $\begin{array}{l}\geq \\
\text { 3years }\end{array}$ \\
\hline $\begin{array}{l}\text { Ismailia } \\
\text { Sharkia } \\
\text { Total }\end{array}$ & $\begin{array}{l}104 \\
20 \\
124\end{array}$ & $\begin{array}{l}10 \\
2 \\
12\end{array}$ & $\begin{array}{l}94 \\
- \\
94\end{array}$ & $\begin{array}{l}- \\
18 \\
18\end{array}$ \\
\hline
\end{tabular}


Table 2. Primers sequences, target genes, amplicon sizes and cycling conditions

\begin{tabular}{|c|c|c|c|c|c|c|c|c|}
\hline \multirow[b]{2}{*}{$\begin{array}{l}\text { Parasite } \\
\text { name }\end{array}$} & \multirow[b]{2}{*}{$\begin{array}{l}\text { Primers sequences } \\
\left(5^{\prime} \rightarrow 3^{\prime}\right)\end{array}$} & \multirow[b]{2}{*}{$\begin{array}{l}\text { Amp. } \\
\text { seg. } \\
\text { (bp) }\end{array}$} & \multirow[b]{2}{*}{$\begin{array}{l}1^{\text {st }} \\
\text { De. }\end{array}$} & \multicolumn{3}{|c|}{ Amplification } & \multirow[b]{2}{*}{$\begin{array}{l}\text { F. } \\
\text { Ex. }\end{array}$} & \multirow[b]{2}{*}{ Ref. } \\
\hline & & & & $2^{\text {nd }} \mathrm{De}$ & An. & Ex. & & \\
\hline \multirow{3}{*}{$\begin{array}{l}\text { Babesia } \\
\text { bovis }\end{array}$} & $\begin{array}{l}\text { BoF } \\
\text { 5'CACGAGGAAGGAACTACCGATGTTGA3' }\end{array}$ & \multirow{2}{*}{356} & \multirow{2}{*}{$\begin{array}{l}94^{\circ} \mathrm{C} \\
5 \\
\min .\end{array}$} & \multirow[t]{2}{*}{$\begin{array}{l}94^{\circ} \mathrm{C} \\
1 \mathrm{~min}\end{array}$} & \multirow[t]{2}{*}{$\begin{array}{l}55^{\circ} \mathrm{C} \\
1 \mathrm{~min}\end{array}$} & \multirow[t]{2}{*}{$\begin{array}{l}72^{\circ} \mathrm{C} \\
1 \mathrm{~min}\end{array}$} & \multirow{2}{*}{$\begin{array}{l}72^{\circ} \mathrm{C} \\
10 \\
\min .\end{array}$} & \multirow{2}{*}{$\begin{array}{l}\text { Figueroa } \\
\text { et al. } \\
(1993)\end{array}$} \\
\hline & $\begin{array}{l}\text { BoR } \\
\text { 5'CCAAGGAGCTTCAACGTACGAGGTCA3' }\end{array}$ & & & & & & & \\
\hline & & & & \multicolumn{3}{|c|}{35 cycles } & & \\
\hline \multirow{3}{*}{$\begin{array}{l}\text { Babesia } \\
\text { bigemina }\end{array}$} & $\begin{array}{l}\text { BilA } \\
\text { 5'CATCTAАТTTСТСТССАТАССССТССЗ' }\end{array}$ & \multirow[t]{2}{*}{278} & \multirow[t]{2}{*}{$\begin{array}{l}94^{\circ} \mathrm{C} \\
5 \\
\min .\end{array}$} & \multirow[t]{2}{*}{$\begin{array}{l}94^{\circ} \mathrm{C} \\
1 \mathrm{~min}\end{array}$} & \multirow[t]{2}{*}{$\begin{array}{l}55^{\circ} \mathrm{C} \\
1 \mathrm{~min}\end{array}$} & \multirow[t]{2}{*}{$\begin{array}{l}72^{\circ} \mathrm{C} \\
1 \mathrm{~min}\end{array}$} & \multirow{2}{*}{$\begin{array}{l}72^{\circ} \mathrm{C} \\
10 \\
\text { min. }\end{array}$} & \multirow{2}{*}{$\begin{array}{l}\text { Figueroa } \\
\text { et al. } \\
\text { (1993) }\end{array}$} \\
\hline & $\begin{array}{l}\text { BilB } \\
\text { 5'CCTCGGCTTCAACTCTGATGCCAAAG3' }\end{array}$ & & & & & & & \\
\hline & & & & \multicolumn{3}{|c|}{35 cycles } & & \\
\hline \multirow[t]{2}{*}{$\begin{array}{l}\text { Theileria } \\
\text { annulata }\end{array}$} & $\begin{array}{l}\text { Tams1F } \\
\text { 5'ATGCTGCAAATGAGGAT3' }\end{array}$ & 785 & $\begin{array}{l}94^{\circ} \mathrm{C} \\
3 \\
\min .\end{array}$ & $\begin{array}{l}94^{\circ} \mathrm{C} \\
1 \mathrm{~min}\end{array}$ & $\begin{array}{l}60^{\circ} \mathrm{C} \\
1 \\
\min .\end{array}$ & $\begin{array}{l}72^{\circ} \mathrm{C} \\
1 \mathrm{~min} .\end{array}$ & $\begin{array}{l}72^{\circ} \mathrm{C} \\
10 \\
\text { min. }\end{array}$ & $\begin{array}{l}\text { Kirvar } \\
\text { et al. } \\
(2000)\end{array}$ \\
\hline & $\begin{array}{l}\text { Tspms1R } \\
\text { 5'GGACTGATGAGAAGACGATGAG3' }\end{array}$ & & & \multicolumn{4}{|c|}{40 cycles } & \\
\hline
\end{tabular}

Amp.: Amplified, seg.: segment, De: Denaturation , An.: Annealing,, Ex.:

Extension, F.: Final and Ref.: References

Table 3. Infection rates of Piroplasmosis in cattle infection by:

a- Microscopical examination in cattle

\begin{tabular}{|c|c|c|c|c|c|}
\hline \multirow{2}{*}{$\begin{array}{l}\text { Examined } \\
\text { animals } \\
\text { number }\end{array}$} & \multirow{2}{*}{$\begin{array}{l}\text { Total } \\
\text { Infected } \\
\text { number } \\
(\%)\end{array}$} & \multicolumn{3}{|c|}{ Single infected number (\%) } & \multirow{2}{*}{$\begin{array}{l}\text { Mixed } \\
\text { infected } \\
\text { number } \\
(\%)\end{array}$} \\
\hline & & $\begin{array}{l}\text { Babesia } \\
\text { bovis }\end{array}$ & $\begin{array}{l}\text { Babesia } \\
\text { bigemina }\end{array}$ & $\begin{array}{l}\text { Theileria } \\
\text { annulata }\end{array}$ & \\
\hline 124 & $\begin{array}{l}72 \\
(58.06 \%)\end{array}$ & $\begin{array}{l}16 \\
(12.90 \%)\end{array}$ & $\begin{array}{l}8 \\
(6.45 \%)\end{array}$ & $\begin{array}{l}48 \\
(38.71 \%)\end{array}$ & $\begin{array}{l}6 \\
(4.84 \%)\end{array}$ \\
\hline
\end{tabular}


Table 4. Infection rates among different age groups of cattle

\begin{tabular}{|l|l|l|l|}
\hline \multirow{2}{*}{ Age group } & \multicolumn{2}{|l|}{ Number of animals } & \multirow{2}{*}{$\%$ of infection } \\
\cline { 2 - 3 } & Examined & Infected & \\
\hline Adult $\geq 3$ years & 18 & 14 & $77.78 \%$ \\
\hline Less than3 months & 12 & 8 & $66.67 \%$ \\
\hline 3- 6 months & 94 & 50 & $53.19 \%$ \\
\hline Total & 124 & 72 & $58.06 \%$ \\
\hline
\end{tabular}

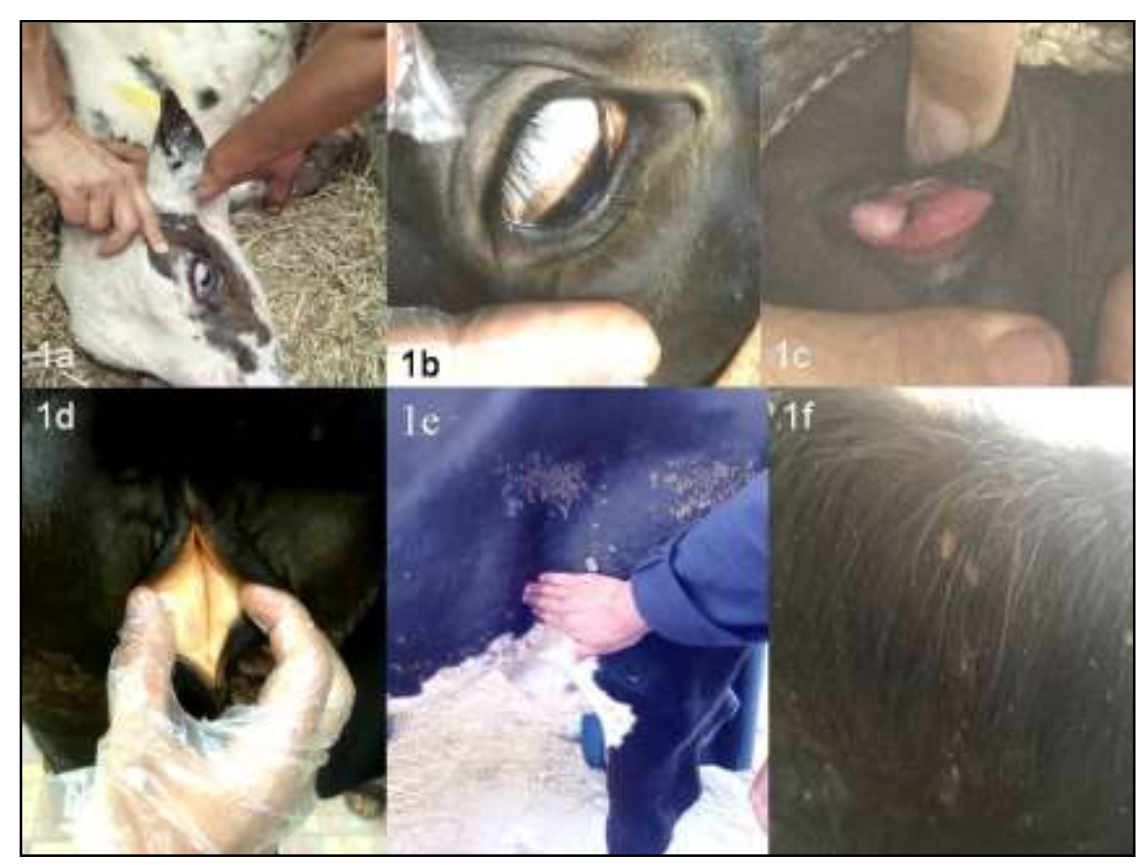

Fig. 1: 1a\&1b) Cattle showed pale conjunctival mucous membrane, 1c) Congested conjunctival mucous membrane, 1d) Icteric vaginal mucous membrane, 1e) Enlarged prefemoral lymph node, 1f) Heavy infested cattle skin with tick (Digital camera). 


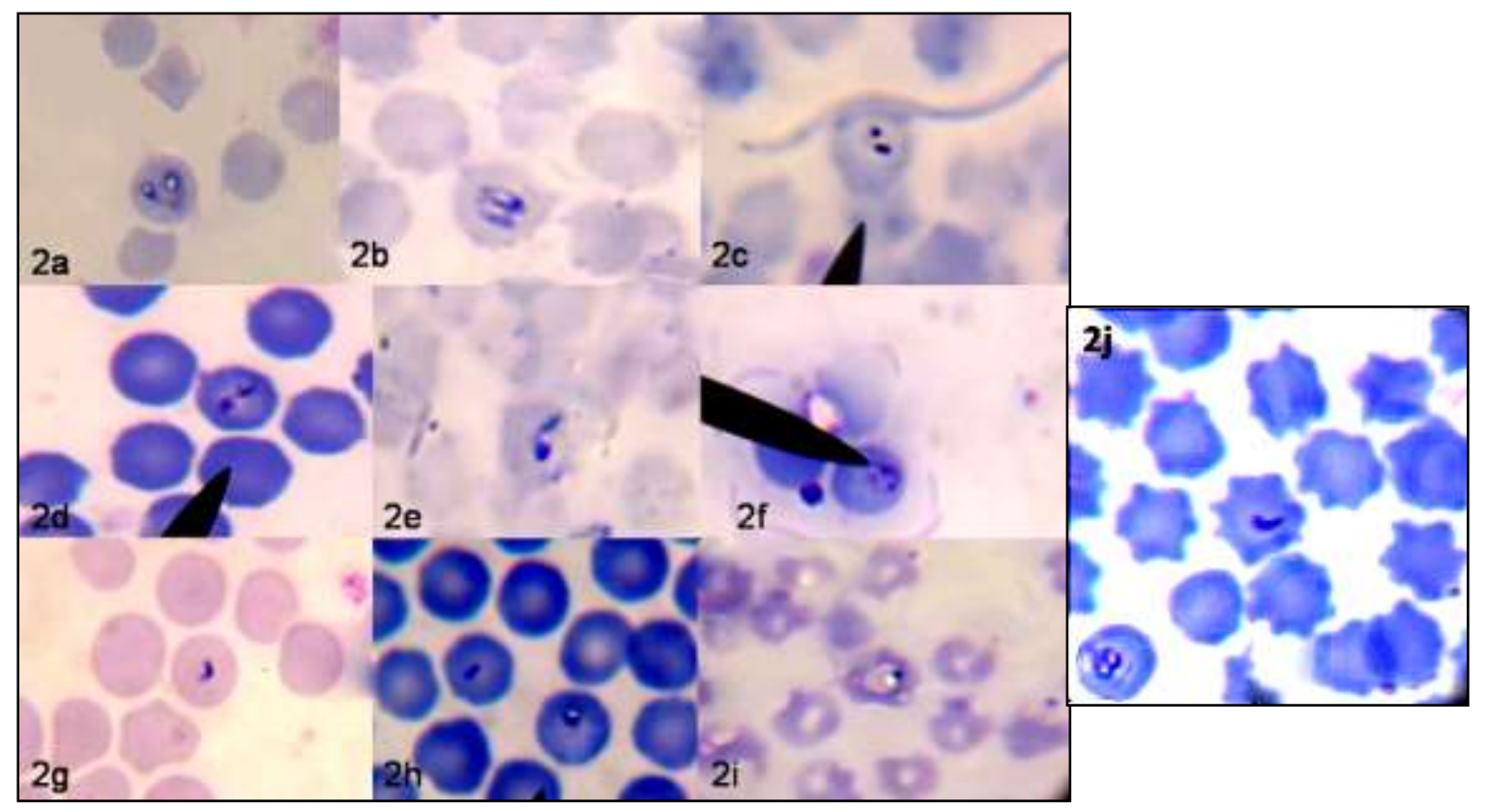

Fig. 2: 2a \&2b) Stained blood films showing Babesia bigemina trophozoites, 2c, 2d \&2e) Stained blood films showing Babesia bovis trophozoites, 2f) Comma shaped Theileria annulata trophozoite, $2 \mathrm{~g}$ ) Rod shaped Theileria annulata trophozoite, $2 \mathrm{~h}$ \&2i) Ring form Theileria annulata trophozoite and 2j) Mixed infection (Digital camera).

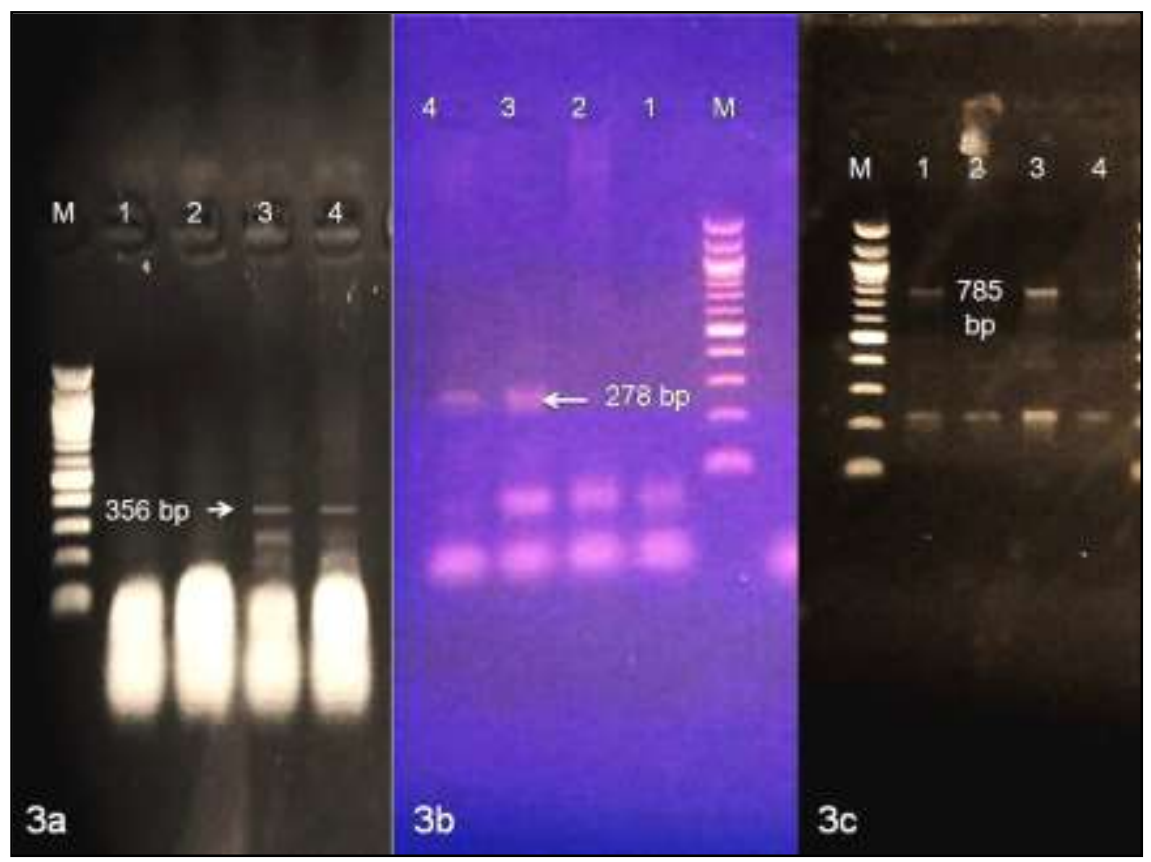

Fig. 3: 3a) Amplified segment (356 bp) for Babesia bovis; 1\&2: -ve, 3\&4: +ve, 3b) Amplified segment (278 bp) for Babesia bigemina; 1\&2: -ve, 3\&4: +ve, 3c) Amplified segment (785bp) for Theileria annulata; $1 \& 3:+v e, 2 \& 4:-v e$, M: DNA marker. 


\section{Discussion}

The observed clinical signs in our study were similar to that described by Rizk et al. (2017). We suspected that these signs were attributed to the replication of Babesia species inside erythrocytes which produced heamolysin and destroy the red cells. This would result in haemoglobnemia, haemoglobnuria, anemia, pale mucous membrane and fever. While, in Theileria annulata the replication occurred inside the lymphocytes causing enlarged lymph nodes, lymphocytopenia and jaundice and might death in case of severe pulmonary oedema. Our explanation was also recorded by

El Moghazy et al. (2014) and Radostitis et al. (2007).

Recently, the 18S rRNA genes have been extensively used as suitable targets for the accurate identification of Babesia species. The conserved regions of $18 \mathrm{~S}$ rRNA gene help in designing primers that can be used to amplify the same gene in the related species. Many authors used PCR for identification and differentiation of Babesia species affecting cattle. In our study, PCR revealed that the length of PCR products was $356 \mathrm{bp}$ and $278 \mathrm{bp}$ for $B$. bovis and B.bigemina, respectively. This result resembled to that obtained by Figueroa et al. (1993). While, the length of the amplified segment was $785 \mathrm{bp}$ for Tams1 gene of $T$. annulata, which was similar to that obtained by Elsify et al. (2015), Kirvar et al. (2000) and Sivakumar et al. (2012).

By Giemsa staining method, we recorded that the infection rate with $B$. bovis was higher than that obtained for $B$. bigemina. They were $12.90 \%$ and $6.45 \%$, respectively. In Egypt, Ibrahim et al. (2013) mentioned that the infection rates were $5.30 \%$ for $B$. bovis and $3.97 \%$ for $B$. bigemina, while, El-Ashker et al. (2015) recorded their rates as the following $7.3 \%$ for $B$. bovis and 1.2 $\%$ for $B$. bigemina. On the contrary, Adham et al. (2009) reported that the infection rate was higher in $B$. bigemina (14\%) than $B$. bovis $(6 \%)$, while Al-Hosary (2017) reported only $B$. bovis infection rate to be 7.9\% in Egypt.

By conventional PCR method, we recorded that the infection rates with $B$. bovis was higher than that obtained for $B$. bigemina. They were $35 \%$ and $20 \%$, respectively. On the contrary, Adham et al. (2009) reported that the infection rate was higher in $B$. bigemina $(60 \%)$ than B. bovis $(55 \%)$ in Egypt. Lower rates were recorded by Ibrahim et al. (2009) to be $17 \%$ for $B$. bovis and $9 \%$ for $B$. bigemina in Egypt. Also, Liu et al. (2012) recorded the lower infection rates in China to be $9.6 \%$ for $B$. bovis and $5.4 \%$ for B. bigemina. AlHosary (2017) reported the infection rate with $B$. bovis to be $17.1 \%$ in Egypt.

By Giemsa staining method, we recorded that the infection rate with Theileria annulata was $38.71 \%$. 
Nearly similar rates were reported in Egypt to be $30 \%$ by Mahmmod et al. (2010), 25.37\% in India by Khatoon et al. (2015), but lower rates $(14.61 \%)$ were reported in Egypt by El Moghazy et al. (2014), $6.25 \%$ in Iran by Hoghooghi-Rad et al. (2011), 13\% in Egypt by Ibrahim et al. (2009), 12.93\% in India by Kundave et al. (2015), $16 \%$ in India by Roy et al. (2000), $10.66 \%$ in Iran by Nourollahi-Fard et al. (2015), and $8.82 \%$ in India by Sahoo et al. (2017). On the contrary to our results, the higher rates of infection were recorded in Egypt to be $65.4 \%$ by Gamal ElDien (1993).

By conventional PCR method, we recorded that the infection rate with Theileria annulata was $60 \%$. However, Mahmmod et al. (2010) in Egypt and Khatoon et al. (2015) and Kundave et al. (2015) in India reported that the infection rates were $70 \%, 74.63 \%$ and $63.79 \%$, respectively. While, lower rates of infection were recorded as the following: $9.56 \%$ in Egypt by Elsify et al. (2015), 44\% in India by Roy et al. (2000), $45.33 \%$ in Iran by Nourollahi-Fard et al. (2015), $32.35 \%$ in India by Sahoo et al. (2017) and $9.8 \%$ in Sri Lanka by Sivakumar et al. (2012).

The difference in infection rates between $B$. bovis, $B$. bigemina and $T$. annulata was due to the fact that the frequency for detection of infection with Babesia species decreased in case of low parasitemias less than $10^{-4} \%$ Calder et al. (1996). We returned the differences in infection rates to the geographical, climatic distribution and the system of breeding, in addition to the presence of varied species of hard ticks which played important role in biological transmission of babesiosis and theileriosis.

When we compared our obtained infection rates in different age groups of cattle $(77.78 \%$ for adult age group, $66.67 \%$ for less than 3 months age group and $53.19 \%$ for 3-6 months age group) with those obtained by Kundave et al. (2015) and Utech and Wharton (1982), we found similarity between the infection rates of adult and 3-6 months age groups. Also, we found that young ages were more resistant to the infection than adult ages. On the contrary to Kundave et al. (2015), our results revealed that the infection rate in age group $<3$ months was higher and that may be due to entry of newly imported cattle to the farm which might carry different strains of Babesia and Theileria species. In addition, the imported and crossbred cattle were more susceptible to the infection than the local breeds. This theory had also been proposed by El Hussein et al. (1991). Also, we suggest that the improper use of acaricidal agents drive cattle to develop less sufficient immunity against infection and so the maternal immunity will be insufficient to protect their calves from babesiosis and theileriosis.

Our study showed that the treatment trials for individual cases were effective. This result was 
agreed with that obtained by Ganga et al. (2010) and Gharbi et al. (2017). While, in case of cattle treated at a Wadi Almullak farm showed bad response and so we suggested that this might due to improper application of the acaricides on the cattle skin and low hygienic surrounding environment. This also was similar to that reported by Rizk et al. (2017). In addition, the uncontrolled continuous entry of new individuals increases the incidence of reinfection. So we advised the owners in the farm for the regular and proper usage of acaricides inside hygienically prepared dipping path for animals and also for the surrounding the environment.

In conclusion, our study proved that using of specific primers in PCR was a rapid and an accurate method for differential diagnosis between $B$. bovis, $B$. bigemina and $T$. annulata in blood samples of cattle. Also, our results revealed that the usage of conventional PCR is more efficient than Giemsa staining method for diagnosis of babesiosis and theileriosis. However, the use of staining technique is most helpful in cases of mixed infections with blood parasites. So we recommend using them together to get better results.

\section{References}

Adham, F.K.; Abd-el-Samie, E.M.; Gabre, R.M. and El-Hussein, $H$. (2009): Detection of tick blood parasites in Egypt using PCR assay I-Babesia bovis and Babesia bigemina. Parasit. Res., 105:721730.

Al-Hosary, A.A.T. (2017): Comparison between conventional and molecular methods for diagnosis of bovine babesiosis (Babesia bovis infection) in tick infested cattle in upper Egypt. J. of Parasit. Dis., 41:243-246.

Brown, C.G. (1990): Control of tropical theileriosis (Theileria annulata infection) of cattle. Parassit., 32:23-31.

Calder, J.A.; Reddy, G.R., Chieves, L.; Courtney, C.H.; Littell, R.; Livengood, J.R.; Norval, R.A.; Smith, C. and Dame, J.B. (1996): Monitoring Babesia bovis infections in cattle by using PCR-based tests. J. of Clin. Micro., 34: 2748-2755.

El-Ashker, M.; Hotzel, H.; Gwida, M.; El-Beskawy, M.; Silaghi C. and Tomaso, H. (2015): Molecular biological identification of Babesia, Theileria, and Anaplasma species in cattle in Egypt using PCR assays, gene sequence analysis and a novel DNA microarray. Vet. Parasit., 207:329-334.

ElHussein, A.M.; Mohamed, S.A.; Osman, A.K. and Osman, O.M. (1991): A preliminary survey of blood parasites and brucellosis in dairy cattle in northern state.Sudan J. Vet. Res.; 10:51-56.

ElMoghazy, H.; Ebied, M.; Abdelwahab, M. and El Sayed, A. (2014):Epidemiological studies on bovine babesiosis and theileriosis in Qalubia governorate. Benha Vet. Med. J., 27:36-48.

Elsify, A.; Sivakumar, T.; Nayel, M.; Salama, A.; Elkhtam, A.; Rizk, M.; Mosaab, O.;Sultan, K.; Elsayed, S.; 
Igarashi, I. and Yokoyama, N. (2015): An epidemiological survey of bovine Babesia and Theileria parasites in cattle, buffaloes, and sheep in Egypt. Parasit. Intern., 64:79-85.

Figueroa, J.V.; Chieves, L.P.; Johnson, G.S. and Buening, G.M. (1993): Multiplex polymerase chain reaction based assay for the detection of Babesia bigemina, Babesia bovis and Anaplasma marginale DNA in bovine blood. Vet. Parasit., 50:69-81.

Gamal El-Dien, H.Y. (1993):

Studies on Theileria protozoan among cattle in Behera Province. Master Faculty of Veterinary Medicine, Alexandria University, Egypt.

Ganga, N.; Ananda, K.J. and Kavitha, R.B. (2010): Theileriosis in calves and its successful treatment. Vet.World, 3:191.

Gharbi, M.; Souidi, K.; Boussaadoun, M.; Rejeb, A.; Jabloun, S.; Gnaoui, A. and Darghouth, M. (2017): Dermatological symptoms in tropical theileriosis (Theileria annulata infection). Rev. Sci. Tech. Off. Int. Epiz., 36:1-20.

Hoghooghi-Rad, N.; Ghaemi, P.; Shayan, P.; Eckert, B. and SadrShirazi, N. (2011):Detection of native carrier cattle infected with Theileria annulata by semi-nested PCR and smear method in Golestan Province of Iran .World App. Sci. J., 12:317-323.

Ibrahim, A.k.; EL Behairy, A.M.; Mahran, K.A. and Awad, W.S. (2009): Clinical and laboratory diagnosis of piroplasmids in naturally infected cattle in Egypt. J. Egypt.Vet. Med. Assoc., 69:191203.

Ibrahim, H.M.; Adjou, M.P.F.; Mohammed-Geba, K.; Sheir, S.K.; Hashem, I.S. and Cao, S. (2013): Molecular and serological prevalence of Babesia bigemina and Babesia bovis in cattle and water buffalos under small-scale dairy farming in Beheira and Faiyum Provinces, Egypt. Vet. Parasit., 198:187-192.

Inci, A.; Ica, A.; Yildirim, A.; Vatansever, Z.; Cakmak, A.; Albasan, H.; Cam, Y.; Atasever, A.; Sariozkan, S. and Duzlu, O. (2007): Economical impact of tropical theileriosis in the Cappadocia region of Turkey. Parasit. Res., 101 (2): 171-174.

Khatoon, S.; Kolte, S.W.; Kurkure, N.V.; Chopde, N.A. and Jahan, A. (2015):Detection of tropical bovine theileriosis by polymerase chain reaction in cattle. J. of Parasit. Dis., 39:53-56.

Kirvar, E.; Ilhan, T.; Katzer, F.; Hooshmand-Rad, P.; Zweygarth, E.; Gerstenberg, C.;Phipps, P. and Brown, C.G.D. (2000): Detection of Theileria annulata in cattle and vector ticks by PCR using the Tams1 gene sequences. Parasit., 120 (3):245-254.

Kundave, V.R.; Patel, A.K.; Patel, P.V.; Hasnani, J.J. and Joshi, C.G. (2015): Detection of theileriosis in cattle and buffaloes by polymerase chain reaction. J.of Parasit. Dis., 39:508-513.

Liu, A.; Guan, G.; Du, P.; Gou, H.; Liu, Z.; Liu, J.; Ma, M.; Yang, J.; Li, Y.; Niu, Q.; Ren, Q.; Bai, Q.; Yin, H. 
and Luo, J. (2012): Loop-mediated isothermal amplification (LAMP) method based on two speciesspecific primer sets for the rapid identification of Chinese Babesia bovis and $B$. bigemina. Parasit. Inter., 61:658-663.

Mahmmod, Y.; El-Balkemy, F.; Yuan, Z.; El-Mekkawy, M.; Monazie, A. and Zhu, X. (2010): Field evaluation of PCR assays for the diagnosis of tropical theileriosis in cattle and water buffaloes in Egypt. J. Ani. Vet. Adv., 9:696-699. Mosqueda, J.; Olvera-Ramirez, A.; Aguilar-Tipacamu, G. and Canto, G.J. (2012): Current advances in detection and treatment of babesiosis. Cur. med.Chem., 19:1504-1518.

Nagati, H.E. (1947): Some new and rare records of piroplasmosis with a list of the species of Babesia and Theileria so far recorded from Egypt. Vet. Rec., 59:145-147.

Nourollahi-Fard, S.R.; Khalili, M. and Ghalekhani, N. (2015): Detection of Theileria annulata in blood samples of native cattle by PCR and smear method in Southeast of Iran. J. of Parasit. Dis., 39:249-252.

Radostitis, O.M.; Gay, C.C.; Hinchiff, K. and Constable, P.D. (2007): Veterinary medicine, a text book of the diseases of cattle, horse, sheep and goats vol 10th ed.LTD, London.

Rizk, M.A.; Salama, A.; El-Sayed, S. A.; Elsify, A.; El-Ashkar, M.; Ibrahim, $\mathrm{H}$.; Youssef, M. and El-Khodery, S. (2017): Animal level risk factors associated with
Babesia and Theileria infections in cattle in Egypt. Acta Parasit., 62:796804 .

Rosenberger, G.; Dirksen, G.; Grunder. H.; Grunert, E. and Krause, D.M.S. (1979): Clinical examination of cattle vol 2nd Ed. Verlag Paul Parey, Berlin and Hamburg.

Roy, K.C.; Ray, D.; Bansal, G.C. and Singh, R.K. (2000): Detection of Theileria annulata carrier cattle by PCR. Ind. J. of Exp. Bio,.38:283-284.

Sahoo, N.; Behera, B.K.; Khuntia, H.K. and Dash, M. (2017): Prevalence of carrier state theileriosis in lactating cows. Vet. World, 10:1471-1474.

Sivakumar, T.; Kothalawala, H.; Abeyratne, S.A.E.; Vimalakumar, S.C.; Meewewa A.S.; Hadirampela, D.T.; Puvirajan, T.; Sukumar, S.; Kuleswarakumar, K.; Chandrasiri, A.D.N.; Igarashi. I. and Yokoyama, N.A. (2012): A PCR-based survey of selected Babesia and Theileria parasites in cattle in Sri Lanka. Vet. Parasit., 190:263-267.

Soulsby, E.J.L. (1982): Helminths, arthropods and protozoa of domesticated animals vol 7th edn. Baillier Tindall and Cassel Ltd, London.

Utech, K.B. and Wharton, R.H. (1982): Breeding for resistance to Boophilus microplus in Australian Illawarra Shorthorn and Brahman $x$ Australian Illawarra Shorthorn cattle. Aust. Vet. J., 58:41-46.

Zintl, A.; Mulcahy, G.; Skerrett, H.E.; Taylor, S.M. and Gray, J.S. (2003): Babesia divergens, a bovine blood parasite of veterinary and zoonotic importance. Clin.

Micro. Rev., 16:622-636. 


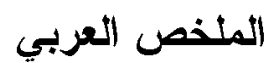

دراسه مقارنه نتخخيص مرض البابيزيوسيس و الثيليريوسيس في الاعمار المختلفة من الأبقار فى بعض المناطق - دصر

$$
\text { "منى محمد إيز اهيب عبدالزحمن -**" وفاء محمد اسماعيل" }
$$

*قنم الطفيليات و **"طب الحيو ان -كلية الطب النيطرى- جامعة الز قازيق

يعد طفيل بابيزيا بوفيس و بابيزيا بايجيمينا وثثليريا انبو لاتا من أهم طفيليات الدم المستوطنة في

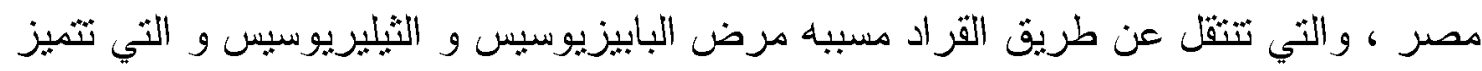

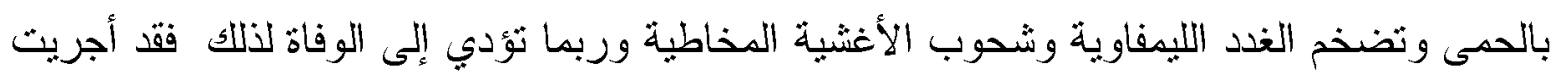
هذه الدراسة لتحديد معدلات الإصابة فى الأعمار المختلفة من الأبقار وقد كانت على الألى النحو التالي:

بالفحص المجهرى لعينات الام التى قد تم صبغها باستخدام صبغه جيمسا قد بلغت معدلات الإصابة 12.90 ٪ ، 6.45 ٪ ، 38.71 ٪ و 4.84 ٪ لكل من بابيزيا بوفيس و بابيزيا بايجيمينا وثيليريا

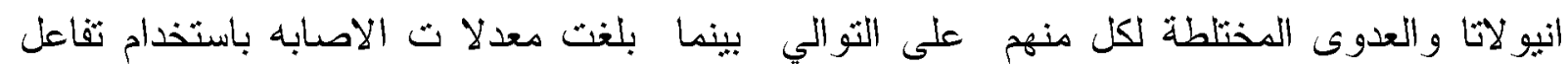
البلمرة المنسلسل (PCR) 35 ٪ و 20 ٪ و 60 \% لكل من بابيزيا بوفيس و بابيزيا بايجيمينا وثيليريا

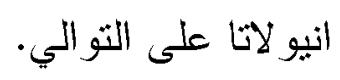

بالإضافة إلى ذلك فقد أوضحت الدراسة حدوث العدوى في الفئات العمرية المختلفة من الأبقار وقد

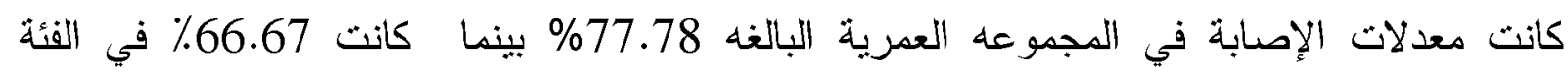
العمرية الأقل من ثلاثه أثهر وأقل معدلات اصابه نم تسجيلها كانت فى الفئه العمرية من ثلاثة إلى فئل

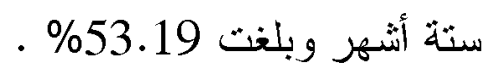
وقد اكدت الدراسه أيضا ان استخدام عقار الإيميدوكارب و البيوبارثوكون بجانب مضادات العنكييات تعثبر من افضل الطرق المستخدمة فى العلاج.

و بالرغم من أن نتائج الدراسه قد أثبتت أن استخدام تفاعل البلمره المنسلسل باستخدام البريمرات

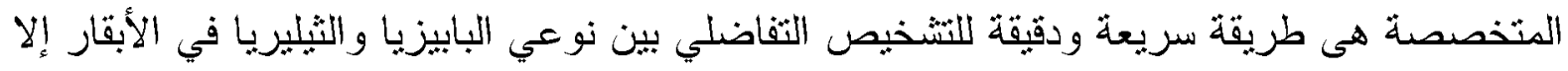

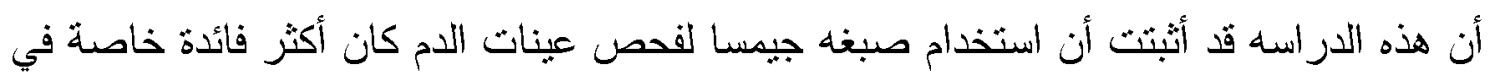

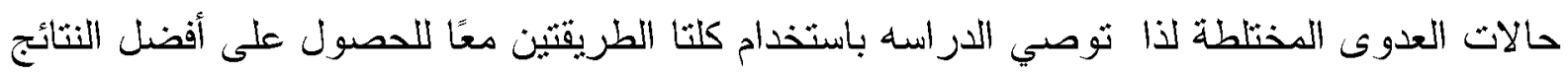
لتتخيص طفيليات الدم فى الأعمار المختلفة من الأبقار 